\title{
Yog is able to Control Body, Mind and Behaviour A Study Report
}

\author{
Niladri Sekhar Ghosh* \\ Department of Social Work, Sai Nath University, India
}

Submission: May 04, 2018; Published: June 05, 2018

"Corresponding author: Niladri Sekhar Ghosh, Department of Social Work, Sai Nath University, Ranchi, India, Tel: 7059437652; Email: niladri. socialwork@gmail.com

\begin{abstract}
On the way of modernization and scientific development society has been enriched lot of facilities related to medical service, educational opportunity, recreation and sensual pleasure but in other hand social values, principals and ethics are going to down. People are pulling by a dissatisfactory aspiration of human mind. In ancient time society had been balanced by the regulation of civil duties by every person but gradually it was also isolated from society. Concept of "yog" also a part of civil duties and according to ancient literatures it is able to control human body, mind and behaviour. During this study it was tried to find out the perfect principal of yog practice. Indeed, it is observed "yog" is able to control 39 different kind of behavioural approaches and on this regards 15 types of practicing regulation is best.
\end{abstract}

Keywords: Impact of yog on behaviour; Ideal regulation of yog practice

\section{Introduction}

Ideologically communal relationship and bonding between more than one people is renowned as a seed of society but in present time people are busy with game of acquisitiveness related to the power, authority and position. Conceptually interpersonal bonding, peacefully living is fundamental content of a society. Literally these are engulfed by market economy and consumerist culture. Literature, the mirror of society has been signifying that during the way of transforming process life came in earth on millions years ago and unorganized human beings were preferred to go with organized life style for the effect of fear from natural disaster. Under the process of development uncivilized primordial human civilization was flourished in earth in-between 10,000 to 8,000BC (The Arctic Home in the Vedas by Bal Gangadhar Tilak). Indian civilization has been renowned as an old civilization in world history. Mr. Naeem Tahir declared on his book "Melluhas of the Indus valley 8,000 -500BC" that Indus valley civilization was existed 5,000 years ago on the bank of the Indus. Veda, The first literature in world was formed in myth of India in-between $6000 \mathrm{BC}$ to $5000 \mathrm{BC}$ [1]. Vedic text has always been proposed a way to enrich the knowledge about ancient society and culture of India.

Along with infrastructural development, promotion of consumerist culture and dissatisfactory life style, growing number of diseases, humiliating incident are also became a part of present society- this is the global scenario. People are pulling by dissatisfactory aspiration of primordial mind. Sensual enjoyment, techno-depended mechanized life, animalistic attitude, infirmity life style is common in this era. Yet, problems and challenges are common features of every society- it was, it is and it will exist in future also. As on the regulation of nature so many practices are adding, modifying and isolating from society. However the concept of "Right" and "Wrong" had not specified in Vedic era but it is observed from the manuscript related to post-Vedic period that ancient sages were identified the tendency of wildness or animalistic behaviour on human character and as an solution they introduced regulation of life with the name of "Civil duty". Indeed physical, mental and behavioural control is the core content of the civil duty. Continuously up growing number of incident such as sexual harassment, molestation, trafficking and rape, destroying life by different weapon, fighting for property, robbery and gambling, addiction are also became a part of modernization. Inside of development index social control and barrier are gradually going down. Similarly, humanity, solidarity, morality, honesty and social ethics are failed to fight with dissatisfactory aspiration of a person. People are born as a baby, not a criminal or nobler - as an outcome of situation people are enriched immoral or moral personality. Simultaneously arising numbers of polarize topics such as "Law" and "Crime", "Medicine" and "Disease", "Academic up gradation" and "Humiliating attitude", "Availability of consumer product" and "Dissatisfactory aspiration" etc are clearly indicating that materialize development is not the perfect indicator of modernization. "Self control" as well as "Social 
control" is most important than infrastructural and technological development.

According to direction of ancient literatures "Yog" practice is best and easily way to control human body, mind and attitude. Yet, Yog is well known name in $21^{\text {st }}$ century, even it is observed that the acceptance of $y o g$ practices are increased day by day from last few years. Perhaps, the perception of yog practice existed in Indian culture from earlier time however in present society the conception of yoga has defined as a process or method of wealthy figure and fruitful mind. Ideologically it is far away from philosophy of yog in Vedic texts. According the subjective sense $y o g$ is the relation between different components. For the effect of globalization and modernization not only the name of yog, even the conception of $y o g$ is also changed by thousands years socialization process. Conception of $y o g$ is used on various aspects in different literature but the philosophy of yog is itself a unique philosophy under six schools of philosophy. "Yogas chitta vritti nirodhah" means "Yog is the removal of the fluctuations of the mind" under Yog Sutra [2] is the formal definition of yog introduce by Maharishi Patanjali, the inventor of yog. Yog converted to Yoga for the trend of modernization and globalization.

Reason to verify the theoretical expectation of yog this study had conducted with 100 youth population of a megacity and it surrounding areas. In this study overall 39 psycho-behavioural components related to daily life of a person had been selected to observe the effect of $y o g$ practice. These 39 psycho-behavioural components are i.e.- Depression, Frustration, Grief, Insecurity, Jealousy, Mental irritation, Nervousness, Stress, Tension, Annoy, Quarrel intention, Malicious intention, Mental calmness, Altruism, Patience, Social accountability, Self-Confidence, Empathic outlook, Integrity, Non-judgmental attitude, Nonviolence attitude, Punctuality, Dignity, Acceptance, Adjustment, Attention, Concentration, Impartiality, Decision-making time, Emotional control, Eye-hand coordination, Recollection, Notice and situation analysis, Reacting/ responding time, Avoiding unwanted circumstance, Manner, Politeness, Solidarity, Cheerful view respectively.

\section{Research Metrology}

Research methodology is the spirit of successful research. In this study the research designing was interpreted as follows process:

\section{Geographical limitation}

The geographical limitation of this study was bounded in the urban region of KMA (Kolkata Metropolitan Area) area of West Bengal, India, according to the area map of Kolkata Metropolitan Authority.

Table 1: Below mention regulation chart was used to identify the best regulation of yog practice.

\begin{tabular}{|c|c|c|c|c|c|c|c|c|c|c|c|}
\hline Sl. No & Code & Sl. No & Code & Sl. No & Code & Sl. No & Code & Sl. No & Code & Sl. No & Code \\
\hline 1 & SAAA & 10 & SBAA & 19 & SCAA & 28 & MAAA & 37 & MBAA & 46 & MCAA \\
\hline 2 & SAAB & 11 & SBAB & 20 & SCAB & 29 & MAAB & 38 & MBAB & 47 & MCAB \\
\hline
\end{tabular}


Annals of Social Sciences \& Management studies

\begin{tabular}{|l|l|l|l|l|l|l|l|l|l|l|l|}
\hline 3 & SAAC & 12 & SBAC & 21 & SCAC & 30 & MAAC & 39 & MBAC & 48 & MCAC \\
\hline 4 & SABA & 13 & SBBA & 22 & SCBA & 31 & MABA & 40 & MBBA & 49 & MCBA \\
\hline 5 & SABB & 14 & SBBB & 23 & SCBB & 32 & MABB & 41 & MBBB & 50 & MCBB \\
\hline 6 & SABC & 15 & SBBC & 24 & SCBC & 33 & MABC & 42 & MBBC & 51 & MCBC \\
\hline 7 & SACA & 16 & SBCA & 25 & SCCA & 34 & MACA & 43 & MBCA & 52 & MCCA \\
\hline 8 & SACB & 17 & SBCB & 26 & SCCB & 35 & MACB & 44 & MBCB & 53 & MCCB \\
\hline 9 & SACC & 18 & SBCC & 27 & SCCC & 36 & MACC & 45 & MBCC & 54 & MCCC \\
\hline
\end{tabular}

Table 2: Above mention 54 codes were developed on the basis of below mention indicators.

\begin{tabular}{|c|c|c|c|c|c|c|c|}
\hline \multicolumn{2}{|c|}{$\mathbf{1}^{\text {st }}$ Code } & \multicolumn{2}{|c|}{$2^{\text {nd }}$ Code } & \multicolumn{2}{|c|}{$3^{\text {rd }}$ Code } & \multicolumn{2}{|c|}{$4^{\text {th }}$ Code } \\
\hline \multicolumn{2}{|c|}{ Type of Practice } & \multicolumn{2}{|c|}{ Period of Practice } & \multicolumn{2}{|c|}{ Time/s in a Day Practice } & \multicolumn{2}{|c|}{ Time Duration (per Seating) of Practice } \\
\hline Code & Condition & Code & Condition & Code & Condition & Code & Condition \\
\hline$S$ & Single & A & $\begin{array}{c}\text { Below } 5 \text { days in } \\
\text { a week }\end{array}$ & A & 1 time & A & Below 1 hour \\
\hline & Multi & B & 5 days in a week & B & 2 times & B & 1 hour to 2 hours \\
\hline M & $\begin{array}{l}\text { (More than } \\
\text { one type of yog } \\
\text { practice) }\end{array}$ & $\mathrm{C}$ & Regular & $\mathrm{C}$ & $\begin{array}{l}\text { More than } 2 \\
\text { times }\end{array}$ & $\mathrm{C}$ & More than 2 hours \\
\hline
\end{tabular}

\section{Data Analysis and Discussion}

The impact and function of "yog" on attitude of a person is clearly reflected from this study. In present society all are busy in their own schedule, everyone have limited time. With the expectation to propose a concrete principal of yog practice this study had been done. Below mention chat has been indicating the best practice principal of yog practice:

It is clear from above discussion that impact factor yog has depended on the regulation of $y o g$ practice and the regulation has depended on different circumstances.

Table 3 is representing the effect of $y o g$ with the respect of different regulations. Particularly it is observed from above table that 15 regulations are fully able to provide positive changes in daily life. Indeed, out of the total 39 regulations 15 yog practicing regulations i.e.-"SACA", "SBAC", "SBCA", "SBCB", "SCAB", "SCAC", "SCCA", “SCCB", "MAAC", "MABB", "MBAC", “MCAB", “MCAC", "MCCA”, "MCCB" are assured 100\% impact. Although apart from above 15 regulations rest 24 regulations are from rank 2 to rank 24 with individual impact factors i.e.- regulation "MBAA" from $2^{\text {nd }}$ rank with impact value 99.96\%, regulation "MBBA" from $3^{\text {rd }}$ rank with impact $99.93 \%$, regulation "SCBB" from $4^{\text {th }}$ rank with impact $99.88 \%$, regulation "MBAB" from $5^{\text {th }}$ rank with impact $99.84 \%$, regulation "MCAA" from $6^{\text {th }}$ rank with impact $99.83 \%$, regulation "MBBB" from $7^{\text {th }}$ rank with impact $99.81 \%$, regulation "MAAA" from $8^{\text {th }}$ rank with impact $99.80 \%$, regulation "MABA" from $8^{\text {th }}$ rank with impact $99.68 \%$, regulation "MCBA" from $10^{\text {th }}$ rank with impact $99.66 \%$, regulation "SBBA" from $11^{\text {th }}$ rank with impact $99.65 \%$, regulation "MCBB" from $12^{\text {th }}$ rank with impact $99.51 \%$, regulation "MAAB" from $13^{\text {th }}$ rank with impact $99.49 \%$, regulations "SCAA" and "SBAA" from $14^{\text {th }}$ rank with impact $99.44 \%$, regulation "MBCA" from $15^{\text {th }}$ rank with impact $99.36 \%$, regulation "SCBA" from $16^{\text {th }}$ rank with impact $99.07 \%$, regulation "MBCB" from $17^{\text {th }}$ rank with impact $98.72 \%$, regulation "SBAB" from $18^{\text {th }}$ rank with impact $98.50 \%$, regulation "SAAC" from $19^{\text {th }}$ rank with impact $97.95 \%$, regulation "SBBB" from $20^{\text {th }}$ rank with impact $97.78 \%$, regulation "SABA" from $21^{\text {th }}$ rank with impact $93.16 \%$, regulation "SAAB" from $22^{\text {th }}$ rank with impact $92.80 \%$, regulation "SABB" from $23^{\text {rd }}$ rank with impact $88.32 \%$, regulation "SAAA " from $24^{\text {th }}$ rank with impact $85.16 \%$ respectively.

Table 3: Effect of yog with the respect of different regulations.

\begin{tabular}{|c|c|c|c|c|c|}
\hline Practice (Code) & Respondents & Total Score & Score Obtain & Level of Impact (\%) & Rank \\
\hline SAAA & 28 & 1092 & 930 & 85.16 & 24 \\
\hline SAAB & 21 & 819 & 760 & 92.8 & 19 \\
\hline SAAC & 5 & 195 & 191 & 97.95 & 21 \\
\hline SABA & 9 & 351 & 327 & 83.16 & 23 \\
\hline SABB & 18 & 702 & 620 & 100 & 1 \\
\hline SACA & 2 & 78 & 3219 & 99.44 & 14 \\
\hline SBAA & 83 & 3237 & 4072 & 98.5 & 100 \\
\hline SBAB & 106 & 4134 & 351 & & 1 \\
\hline
\end{tabular}


Annals of Social Sciences \& Management studies

\begin{tabular}{|c|c|c|c|c|c|}
\hline SBBA & 22 & 858 & 855 & 99.65 & 11 \\
\hline SBBB & 45 & 1755 & 1716 & 97.78 & 20 \\
\hline SBCA & 1 & 39 & 39 & 100 & 1 \\
\hline SBCB & 3 & 117 & 117 & 100 & 1 \\
\hline SCAA & 50 & 1950 & 1939 & 99.44 & 14 \\
\hline SCAB & 53 & 2067 & 2067 & 100 & 1 \\
\hline SCAC & 7 & 273 & 273 & 100 & 1 \\
\hline SCBA & 11 & 429 & 425 & 99.07 & 16 \\
\hline SCBB & 22 & 858 & 857 & 99.88 & 4 \\
\hline SCCA & 4 & 156 & 156 & 100 & 1 \\
\hline SCCB & 1 & 39 & 39 & 100 & 1 \\
\hline MAAA & 13 & 507 & 506 & 99.8 & 8 \\
\hline MAAB & 20 & 780 & 776 & 99.49 & 13 \\
\hline MAAC & 1 & 39 & 39 & 100 & 1 \\
\hline MABA & 8 & 312 & 311 & 99.68 & 9 \\
\hline MABB & 8 & 312 & 312 & 100 & 1 \\
\hline MBAA & 71 & 2769 & 2768 & 99.96 & 2 \\
\hline MBAB & 128 & 4992 & 4984 & 99.84 & 5 \\
\hline MBAC & 11 & 429 & 429 & 100 & 1 \\
\hline MBBA & 37 & 1443 & 1442 & 99.93 & 3 \\
\hline MBBB & 41 & 1599 & 1596 & 99.81 & 7 \\
\hline MBCA & 4 & 156 & 155 & 99.36 & 15 \\
\hline МВСВ & 2 & 78 & 77 & 98.72 & 17 \\
\hline MCAA & 44 & 1716 & 1713 & 99.83 & 6 \\
\hline MCAB & 53 & 2067 & 2067 & 100 & 1 \\
\hline MCAC & 6 & 234 & 234 & 100 & 1 \\
\hline MCBA & 30 & 1170 & 1166 & 99.66 & 10 \\
\hline MCBB & 21 & 819 & 815 & 99.51 & 12 \\
\hline MCCA & 1 & 39 & 39 & 100 & 1 \\
\hline МСCВ & 1 & 39 & 39 & 100 & 1 \\
\hline Total & 1000 & 39000 & 38499 & 98.72 & \\
\hline
\end{tabular}

\section{Conclusion}

After intervention, the remarkable observation is different impact factors are seeking among same psycho-behavioural component with the respect of different practicing regulation. Therefore, it is concluded that circumstance of yog practice is the main factor to carry the right impact. And on this regards 15 regulations i.e.-"SACA", "SBAC", "SBCA", "SBCB", "SCAB", "SCAC",
"SCCA", “SCCB”, "MAAC", “MABB", “MBAC”, “MCAB", “MCAC”, “MCCA”, "MCCB" are best.

\section{References}

1. The Arctic Home in the Vedas, Chapter-XIII, p. 390.

2. Yog Sutra by Patanjali, Chapter-1, Verse -2. 
This work is licensed under Creative Commons Attribution 4.0 License

DOI: 10.19080/ASM.2018.01.555560
Your next submission with Juniper Publishers will reach you the below assets

- Quality Editorial service

- Swift Peer Review

- Reprints availability

- E-prints Service

- Manuscript Podcast for convenient understanding

- Global attainment for your research

- Manuscript accessibility in different formats ( Pdf, E-pub, Full Text, Audio)

- Unceasing customer service

Track the below URL for one-step submission https://juniperpublishers.com/online-submission.php 